Annals of Warsaw University of Life Sciences - SGGW

Land Reclamation No 44 (1), 2012: 47-54

(Ann. Warsaw Univ. of Life Sci. - SGGW, Land Reclam. 44 (1), 2012)

\title{
Comparison of precipitation totals measured by the automatic telepluviometer and the Hellmann rain gauge at the Warsaw Ursynów station in 2000-2010
}

\author{
DARIUSZ GOŁASZEWSKI, MAŁGORZATA KLENIEWSKA \\ Department of Hydraulic Engineering, Warsaw University of Life Sciences - SGGW
}

\begin{abstract}
Comparison of precipitation totals measured by the automatic telepluviometer and the Hellmann rain gauge at the Warsaw Ursynów station in 2000-2010. Popularization of automatic methods of measuring meteorological elements and substituting manual methods creates a problem of maintaining homogeneity of measurement series. In such situations it is necessary to conduct measurements simultaneously, i.e. using a method being introduced and a former method. The analysis of measurement series carried out simultaneously enables comparing and relating measurements made by a new apparatus to already existing results.

The present paper includes the results of the analysis of differences between daily, monthly and seasonal atmospheric precipitation values coming from a 11-year series of simultaneous measurements with a telepluviometer and the Hellmann rain gauge.
\end{abstract}

Key words: precipitation measurements, atmospheric precipitation, differences in rain gauge indications.

\section{INTRODUCTION}

Replacement of devices used in meteorological measurements or changing the way of conducting measurements from a manual measurement to an automatic one may cause lack of homogeneity of observation series. The situation results in the necessity of assessing the quality of data recorded by new instruments, preferably through conducting simulta- neous measurement series with the use of a newly introduced apparatus and the one used so far.

In the case of measuring precipitation, lack of homogeneity of a measurement series may be brought about by various measuring errors resulting from the construction of instruments, a method of conducting measurements and weather conditions from the beginning of precipitation to the moment of conducting the nearest manual measurement. The issue was dealt with by many researchers: Goodison et al. 1998; Kejna and Uscka-Kowalkowska 2006; Kuśmierek 2006, 2008; Lorenc 2006, Sevruk et al. 2009.

The present work compares two observation series of precipitation values which were carried out simultaneously. The first one was based on the data from automatic measurement made with a telepluviometer and the second one on the data collected using traditional (manual) methods with the use of the Hellmann rain gauge. Both rain gauges were installed at a measuring point of the Warsaw Ursynów station. The analysis of the simultaneously conducted measurement series, among other things, makes possible relating the measurements made with the new device to the already existing multi-annual measurement series. 


\section{MATERIAL AND METHOD}

For the analysis the present study used the results of measurements of atmospheric precipitation from the Warsaw Ursynów meteorological station of SGGW situated in the southern part of the city. The research covered daily precipitation totals from 2000-2010. The expansion of the meteorological station which took place at the beginning of this period and, resulting from it, failures of measurement instruments and servicing problems prevented using some of the gathered data. In connection with the above, the study used daily precipitation totals measured during the warm and cold season of the year, not taking into account short periods when one of the devices was not in operation. In total, the study encompassed 1144 days with precipitation out of which 579 days occurred in the warm season and the rest were recorded in the cold season of the year. The measurements were carried out using a manual method with a standard Hellmann rain gauge and an automatic method with a telepluviometer produced by the compa- ny Theodor Friedrichs. In this instrument the measuring-transmitting unit consists of a tipping bucket (Fig. 1) which makes possible measurements with an accuracy of $0.1 \mathrm{~mm}$ and two independent heating systems which enable its work also in winter months.

The rain gauges from which data were used in the present study (Fig. 2) were located at a measuring point at a distance of 4 meters from each other. The instruments were installed in accordance with a standard employed at meteorological stations (Różdżyński 1996).

Because of lack of full-time observer at the meteorological station, manual measurements were conducted once in 24 hours at 12:00 UTC. Both measurement methods assumed that the precipitation day lasts from 12:00 till midday of the following day (according to UTC).

Having daily totals of precipitation values, differences between the indications of the telepluviometer $\left(\mathrm{P}_{\mathrm{A}}\right)$ and the Hellmann rain gauge $\left(\mathrm{P}_{\mathrm{H}}\right)$ were calculated. In addition, differences in monthly, half-yearly (the warm and cold season of the year) and annual precipitation values

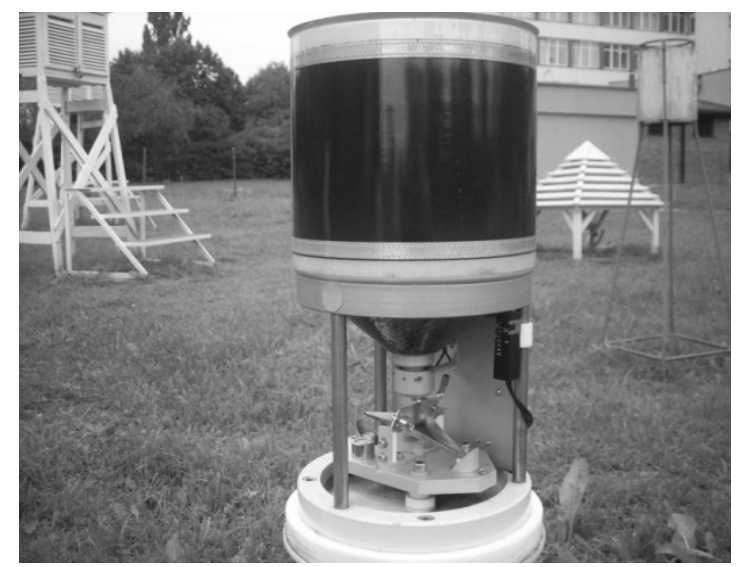

FIGURE 1. Measurement unit in the telepluviometer 


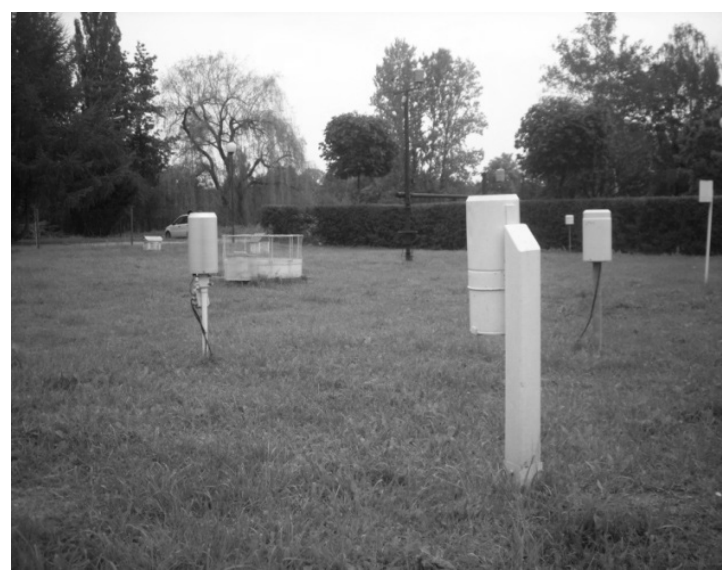

FIGURE 2. Telepluviometer and Hellmann rain gauge at the Warsaw Ursynów station

$\mathrm{P}_{\mathrm{A}}-\mathrm{P}_{\mathrm{H}}$ were determined. Moreover, simple regression analysis was used to determine statistical relationships between the analyzed observation series.

\section{RESULTS}

The differences in annual values of atmospheric precipitation between the examined measurement sequences varied from $-8.3 \mathrm{~mm}$ to $22.3 \mathrm{~mm}$. More frequently they assumed positive values (Table 1), which means higher indications of the telepluviometer. The highest value of the difference $(22.3 \mathrm{~mm})$ was recorded in 2001 when the annual precipitation total amounted to $578.9 \mathrm{~mm}$ and the smallest difference in 2004 with the annual precipitation total of 550.2 $\mathrm{mm}$. During the 11-year research period, negative values of the differences were recorded 5 times: in 2000, 2004, 2005,
2008 and 2010. It was observed that the values of the differences between annual precipitation totals in the subsequent years are marked by a downward trend; thus, the quality of the obtained data was increasingly better.

The differences between monthly precipitation totals measured by the telepluviometer and the Hellmann rain gauge were within a range from $-7.9 \mathrm{~mm}(\mathrm{Au}-$ gust 2008) to $9.2 \mathrm{~mm}$ (May 2001). The biggest differences in the results were recorded in 2001 when the values were within a range from $-4.3 \mathrm{~mm}$ (in November) to $9.5 \mathrm{~mm}$ (in May). In the last of the analyzed years, the discrepancy between the indications of the analyzed rain gauges in particular months changed from $-7.6 \mathrm{~mm}$ in January to $4.7 \mathrm{~mm}$ in April (Fig. 3).

The basis for all analyses of the differences between the indications of the telepluviometer and the Hellmann rain

TABLE 1. Differences between annual precipitation totals measured by the automatic telepluviometer and the Hellmann rain gauge at the Warsaw Ursynów station in 2000-2010

\begin{tabular}{|l|l|l|l|l|l|l|l|l|l|l|l|}
\hline Year & 2000 & 2001 & 2002 & 2003 & 2004 & 2005 & 2006 & 2007 & 2008 & 2009 & 2010 \\
\hline Difference (PA-PH) & -7.6 & 22.3 & 14.3 & 20.6 & -2.0 & -7.0 & 16.7 & 18.5 & -10.3 & 13.9 & -7.8 \\
\hline
\end{tabular}




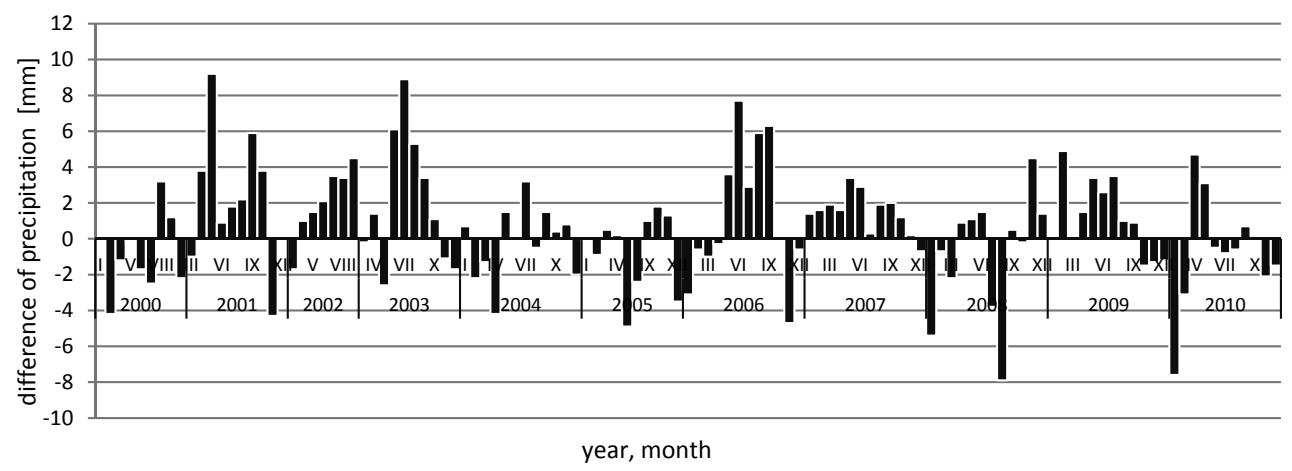

FIGURE 3. Differences in monthly precipitation totals measured by the automatic telepluviometer and the Hellmann rain gauge at Warsaw Ursynów station in 2000-2010

gauge conducted in the present study was daily precipitation values. These differences during the whole analyzed period were within a range from -6.4 to $8.0 \mathrm{~mm}$.

The most frequently occurring value of the differences between daily precipitation totals in the analyzed period (Fig. 4) was $0.1 \mathrm{~mm}$, which constituted $12.5 \%$ of all cases. The second most frequently recorded difference was $0.2 \mathrm{~mm}$, which occurred in $10.7 \%$ of the cases. The same indications of daily precipitation totals by both rain gauges in the course of the 11-year measurement period were recorded 117 times, which constituted $10.2 \%$ of the cases. Assuming that the measurement is equal when the difference between the indications amounts to $0 \pm 0.2 \mathrm{~mm}$ (which results from the accuracy of the instruments), it was recorded 546 times $(47.7 \%)$. The frequency of differences being within a range from -0.5 $\mathrm{mm}$ to $0.5 \mathrm{~mm}$ amounted to $72 \%(831$ cases). Taking into account the division of the analyzed period into the warm half-year (Apr-Sep) and the cold half-year (Oct-Mar), one can notice that a

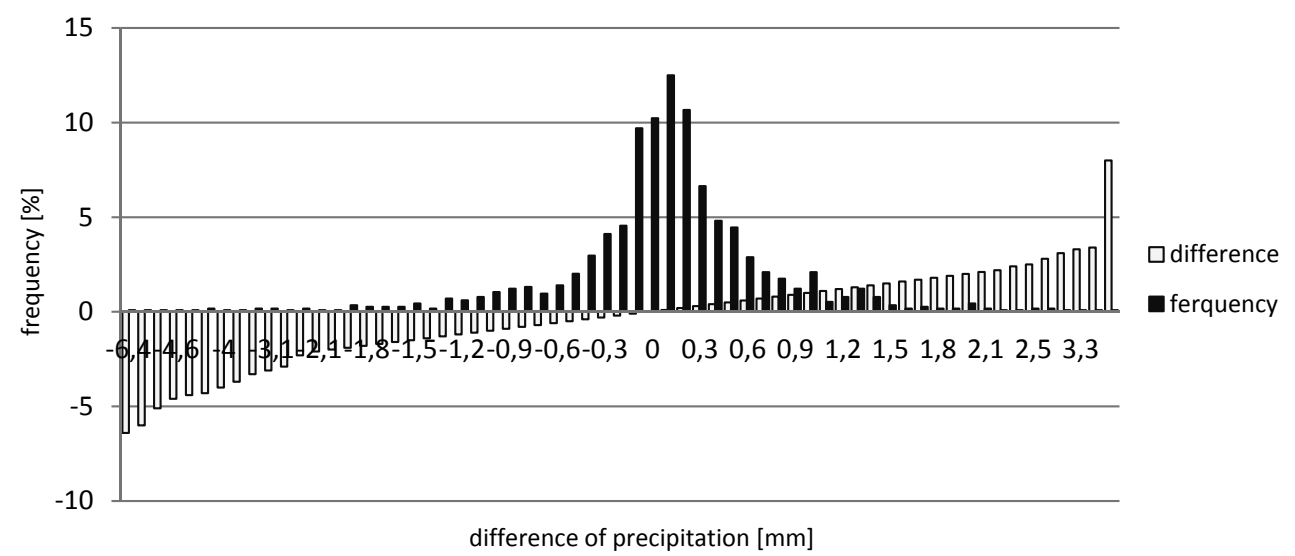

FIGURE 4. Differences in daily precipitation totals measured by the automatic telepluviometer and the Hellmann rain gauge at the Warsaw Ursynów station in 2000-2010 
higher compatibility of measurement results was observed in the warm half-year (Fig. 5). riod, higher values of precipitation totals were recorded more frequently by the Hellmann rain gauge despite negative

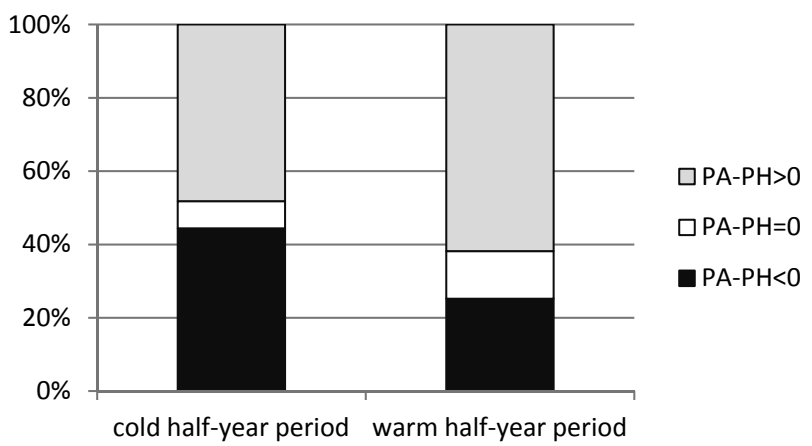

FIGURE 5. Structure of differences in daily precipitation totals at the Warsaw Ursynów station in the cold and warm half-year 2000-2010

In summer months the same indications of the analyzed rain gauges were recorded 75 times, which constituted $13 \%$ of the cases in that season of the year; in the cold half-year 42 such cases were recorded, which constituted $7.4 \%$ of the total number. Using average values of the differences for the warm and cold half-year calculated on the basis of daily data, one can be observe that a higher value is recorded in the warm period, i.e. $+0.2 \mathrm{~mm}$, whereas for the cold half-year it amounts to $-0.1 \mathrm{~mm}$.

After a detailed analysis of the collected data it can be noticed that only in the first and the last year (2000 and 2010) of the analyzed 11-year measurement pe- values of the differences in annual totals in those years. It means less common but significantly higher indications of the telepluviometer during that time.

After considering the division of the analyzed period into the warm half-year (Apr-Sep) and the cold half-year (Oct-Mar), a high diversity of the structure of the calculated differences was observed (Table 2). Positive values of the differences (showing higher indications of the telepluviometer) were recorded in $61.8 \%$ of the cases of days with precipitation in the warm half-year months and negative values of the differences in $13.0 \%$ of the cases. It can be explained by an immediate measurement (without additional

TABLE 2. Structure of differences in daily precipitation totals at the Warsaw Ursynów station in the cold and warm half-year, 2000-2010

\begin{tabular}{|l|c|c|c|c|c|c|}
\hline \multirow{2}{*}{ Specification } & \multicolumn{2}{|c|}{ Whole period } & \multicolumn{2}{c|}{ Warm half-year } & \multicolumn{2}{c|}{ Cold half-year } \\
\cline { 2 - 7 } & $\begin{array}{c}\text { Number } \\
\text { of cases }\end{array}$ & $\begin{array}{c}\text { Frequency } \\
{[\%]}\end{array}$ & $\begin{array}{c}\text { Number } \\
\text { of cases }\end{array}$ & $\begin{array}{c}\text { Frequency } \\
{[\%]}\end{array}$ & $\begin{array}{c}\text { Number } \\
\text { of cases }\end{array}$ & $\begin{array}{c}\text { Frequency } \\
{[\%]}\end{array}$ \\
\hline $\mathrm{PA}-\mathrm{PH}>0$ & 630 & 55.1 & 358 & 61.8 & 272 & 48.2 \\
\hline $\mathrm{PA}-\mathrm{PH}=0$ & 117 & 10.2 & 75 & 13 & 42 & 7.4 \\
\hline $\mathrm{PA}-\mathrm{PH}<0$ & 397 & 34.7 & 146 & 25.2 & 251 & 44.4 \\
\hline
\end{tabular}


losses during evaporation resulting from waiting for a measurement) in the case of the telepluviometer. In the case of the Hellmann rain gauge, the reading of a precipitation value may in extreme cases occur over 20 hours after the occurrence of precipitation. This, combined with relatively high at that time air temperatures which are conducive to higher evaporation, leads to lower indications of this rain gauge. In the cold half-year the differences in daily precipitation totals do not show such a high diversity; positive values of the differences occur with a frequency of $48.2 \%$, and negative ones with $44.4 \%$. It is mainly caused by the operation of the telepluviometer heating system, which, on one hand, enables continuous measurements in winter but, on the other hand, leads to an increase in losses resulting from evaporation.

The most frequently occurring discrepancies of the indications of the analyzed rain gauges $\left(\mathrm{P}_{\mathrm{A}}-\mathrm{P}_{\mathrm{H}}\right)$ are within a range from $+0.1 \mathrm{~mm}$ to $+0.5 \mathrm{~mm}$. Their frequency reaches $40.2 \%$ in the warm half-year and $39.1 \%$ in the cold half-year and, as it can be seen, it is similar in both half-years. Another of the examined ranges, i.e. a range from $-0.5 \mathrm{~mm}$ to $-0.1 \mathrm{~mm}$, occurs significantly less frequently. In this case a distinct difference between the frequency of discrepancies of the indications of the rain gauges in the warm and cold season can be noticed. In months of the warm season of the year the frequency of these discrepancies amounted to $16.9 \%$, whereas in the cold months it reached $29.9 \%$. Only within this range $(-0.5 \div-0.1 \mathrm{~mm})$ the frequency of different indications of the rain gauges was so diverse and depended on a season of the year. In the remaining analyzed ranges (of intervals of $0.5 \mathrm{~mm}$ each), the frequency of divergent indications in the warm and cold season was stable and changed from $2.3 \%$ to $5.8 \%$.

As signaled earlier, in comparison with the cold half-year, in the warm half-year compatibility of the indications of the measurements of daily precipitation totals was recorded more frequently. In Figure 6 it can be seen that the same indications of the rain gauges were recorded most frequently in April and August, i.e. $14.7 \%$ in each, and $12.8 \%$ in September.

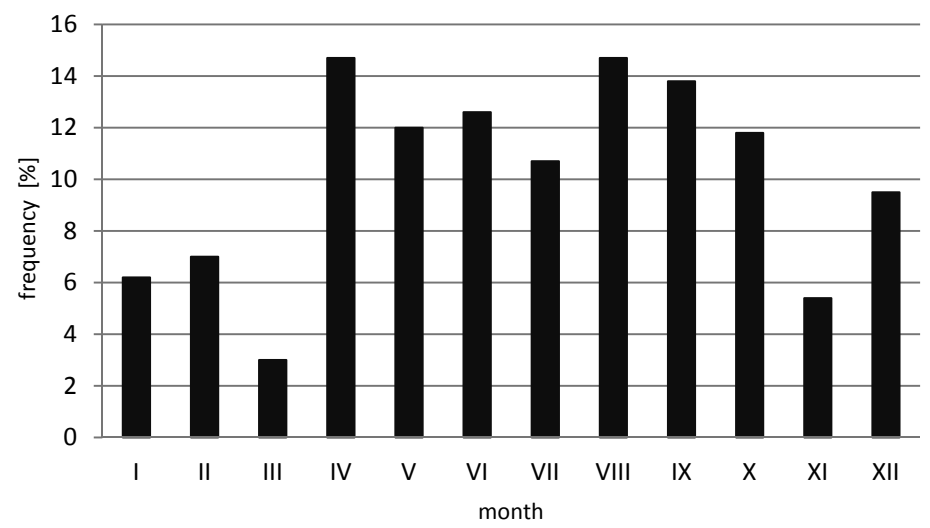

FIGURE 6. Frequency of compatibility of indications of the telepluviometer and the Hellmann rain gauge in particular months 
TABLE 3. Selected statistical characteristics describing the relationship between the values of precipitation totals measured by the telepluviometer and the Hellmann rain gauge

\begin{tabular}{|l|l|c|c|c|c|}
\hline Month & \multicolumn{1}{|c|}{ Equation form } & F-ratio & $\mathrm{r}$ & $\mathrm{R}^{2}$ & $\mathrm{SE}$ \\
\hline $\mathrm{I}$ & $\mathrm{Y}=0.06+1.03 \cdot \mathrm{X}$ & 1916.9 & 97.7 & 95.4 & 1.22 \\
\hline II & $\mathrm{Y}=0.15+0.95 \cdot \mathrm{X}$ & 2477.9 & 98.1 & 96.2 & 0.60 \\
\hline III & $\mathrm{Y}=-0.14+1.1 \cdot \mathrm{X}$ & 4130.0 & 99.6 & 98.3 & 0.49 \\
\hline IV & $\mathrm{Y}=-0.26+1.04 \cdot \mathrm{X}$ & 2152.6 & 98.3 & 96.7 & 0.98 \\
\hline V & $\mathrm{Y}=-0.12+0.99 \cdot \mathrm{X}$ & 6531.1 & 99.3 & 98.5 & 0.99 \\
\hline VI & $\mathrm{Y}=-0.08+0.98 \cdot \mathrm{X}$ & 17171.5 & 99.7 & 99.4 & 0.99 \\
\hline VII & $\mathrm{Y}=-0.02+0.98 \cdot \mathrm{X}$ & 17141.3 & 99.7 & 99.4 & 0.99 \\
\hline VIII & $\mathrm{Y}=-0.24+1.01 \cdot \mathrm{X}$ & 13269.1 & 99.6 & 99.3 & 0.99 \\
\hline IX & $\mathrm{Y}=-0.21+0.98 \cdot \mathrm{X}$ & 15352.7 & 99.7 & 99.4 & 0.99 \\
\hline $\mathrm{X}$ & $\mathrm{Y}=-0.04+0.99 \cdot \mathrm{X}$ & 6074.3 & 99.2 & 98.4 & 0.99 \\
\hline $\mathrm{XI}$ & $\mathrm{Y}=-0.14+1.06 \cdot \mathrm{X}$ & 2939.6 & 98.2 & 96.4 & 0.98 \\
\hline XII & $\mathrm{Y}=-0.01+1.05 \cdot \mathrm{X}$ & 2619.9 & 98.5 & 96.9 & 0.98 \\
\hline IV-IX & $\mathrm{Y}=-0.02+1.03 \cdot \mathrm{X}$ & 16244.9 & 98.3 & 96.7 & 0.85 \\
\hline $\mathrm{X}-\mathrm{III}$ & $\mathrm{Y}=-0.15+0.99 \cdot \mathrm{X}$ & 60972 & 99.5 & 99.1 & 0.78 \\
\hline
\end{tabular}

In the cold season of the year, the frequency of compatibility of the indications is significantly lower and changes from 3\% in March to $9.5 \%$ in December. In October, the frequency of the same indications is similar to the warm season of the year. It results from the course of air temperature, which limits (delays) the need to activate the pluviometer heating system.

Analyzing the statistical relationship between the value of precipitation measured by the Hellmann rain gauge and the telepluviometer, a strong positive correlation was obtained (Table 3). For simple linear regression equations, determining relationships of monthly and seasonal (from the warm and cold halfyear) precipitation totals, determination indexes $\left(\mathrm{R}^{2}\right)$ reached high values. They varied within a range from 95.4 in January to 99.4 in June, July and September. In the warm season of the year $\mathrm{R}^{2}=99.1$ and was slightly higher than the analogical one which was characteristic of the cold season (96.7). All the equations, irrespective of the season of the year, proved to be highly significant statistically $(p=0.01)$.

\section{SUMMARY}

Simple determination of the causes and values of the differences between precipitation totals measured by the Hellmann rain gauge and the telepluviometer is very difficult. One of the factors which undoubtedly limits compatibility of indications is a different method of obtaining data: a periodical method in the case of the Hellmann rain gauge and a continuous one in the case of the telepluviometer. Especially in the warm season it leads to higher losses connected with evaporation in the rain gauge and its 
lower indications. In the warm season of the year, the indications of the Hellmann rain gauge are on average lower by 0.2 $\mathrm{mm}$ than those recorded by the telepluviometer.

In the cold season of the year one should take into account the operation of the telepluviometer heating system. Even slight heating up of telepluviometer operating surfaces, to a small but noticeable degree, leads to its lower indications (in comparison with the Hellmann rain gauge). On average, in the cold season of the year the results of telepluviometer measurements were lower by $0.1 \mathrm{~mm}$ than those recorded by the rain gauge.

However, it can be noticed that the frequency of compatibility of the indications of the Hellmann rain gauge and the telepluviometer in warm season months is higher (from $10.7 \%$ in July to $14.7 \%$ in April and August) from the frequency recorded in the cold season (from 3\% in March to $9.5 \%$ in December).

\section{REFERENCES}

GOODISON B., LOUIE P., YANG D. 1998: WMO solid precipitation measurement intercomparison: final report. Instruments and Observing Methods, WMO/TD no. 872. World Meteorological Organization, WMO Geneva, $211 \mathrm{pp}$.

KEJNA M., USCKA-KOWALKOWSKA J. 2006: Comparison of meteorological data measured by the traditional and automatic methods at the Koniczynka station in 2002. Annales UMCS, Sectio B: Geogr, Geol., Mineralogia et Petrographia, LXI: 208-217 (in Polish).

KUŚMIEREK R. 2006: Comparison of incoming solar radiation measured by different methods. Annales UMCS, Sectio B: Geogr., Geol., Mineralogia et Petrographia LXI, 4, B: 250-255 (in Polish).
KUŚMIEREK R. 2008: The usefulness of automatic weather station for meteorological cover in agriculture. Scientific Review Engineering and Environmental Sciences. Warsaw Univ. of Life Sci. Press, 1 (39), 26-34 (in Polish).

LORENC H. 2006: Quality assessment of meteorological data from automatic sensors in IMGW network. Annales UMCS LXI, 4, B: 256-266 (in Polish).

RÓŻDŻYNSKI K. 1996: Measurement of meteorological variabilities (Miernictwo meteorologiczne). I / II, IMGW, Warsaw (in Polish).

SEVRUK B., ONDRAS M., CHVILA B. 2009: The WMO precipitation measurement intercomparisons. Atmospheric Research 92 (3), 376-380.

Streszczenie: Porównanie sum opadu zmierzonych telepluwiometrem $i$ deszczomierzem Hellmanna i na stacji Ursynów SGGW w latach 2001-2010. Upowszechnienie automatycznych metod pomiaru elementów meteorologicznych i zastępowanie nimi metod manualnych, stwarza problem zachowania jednorodności serii pomiarowych. W takich sytuacjach konieczne jest prowadzenie równoległych pomiarów tj. wprowadzaną metodą i dotychczas stosowaną. Analiza równolegle wykonanych serii pomiarowych pozwala na porównanie i ,dowiązanie" pomiarów nowym przyrządem do już istniejących wyników. W niniejszej pracy zawarto wyniki analizy różnic sum dobowych, miesięcznych i okresowych wysokości opadu atmosferycznego z 11-letniej serii równoczesnych pomiarów telepluwiometrem i deszczomierzem Hellmanna.

Stowa kluczowe: pomiary opadów, opady atmosferyczne, różnice wskazań deszczomierzy.

MS. received March 2012
Authors' address:
Dariusz Gołaszewski, Małgorzata Kleniewska
Katedra Inżynierii Wodnej
Szkoła Główna Gospodarstwa Wiejskiego
ul. Nowoursynowska 166
02-787 Warszawa, Poland
e-mail: dariusz_golaszewski@sggw.pl 